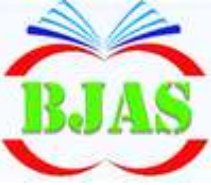

ISSN 1814 - 5868
Available online at http://bjas.bajas.edu.iq

https://doi.org/10.37077/25200860.2021.34.2.08

College of Agriculture, University of Basrah

\title{
Effect of Plant Growth Regulators and Explant Source on the Induction
}

\section{of Callus of Dianthus caryophyllus L.}

\author{
Huda E. Mahood \\ Department of Horticulture, College of Agriculture, University of Al-Qadisiyah, Iraq
}

*Corresponding author email: huda.enaya@qu.edu.iq

Received 7 December 2020; Accepted 12 May 2021; Available online 2 November 2021

\begin{abstract}
In order to investigate the possibility for in in vitro fast regeneration of Dianthus caryophyllus, different concentrations of Kinetin (Kin), 2,4-Dichlorophenoxy Acetic Acid (2,4-D) had been tested for induction of callus by leaves and stems explant using Murashige and Skoog (MS) medium. After two months in culture, response callus in the induction rate, fresh and dry weight, texture and color were evaluated. MS medium that contained $4.5 \mathrm{mg} . \mathrm{L}^{-1} 2$, 4-D was suitable for callus induction with leaf explants. The combination of $0.4 \mathrm{mg} . \mathrm{L}^{-1} \mathrm{Kin}$ and $2.0 \mathrm{mg} . \mathrm{L}^{-1}$ 2, 4-D also demonstrated a wonderful induction of callus on stem explants. In addition to the culture medium complemented by Kin and 2, 4-D, the influence of Zeatin at various concentrations (0.0, $0.4,0.8$ or $1.0 \mathrm{mg} . \mathrm{L}^{-1}$ ) was assessed. In MS medium that contained $0.4 \mathrm{mg} . \mathrm{L}^{-1} \mathrm{Kin}+2.0$ mg.L $\mathrm{L}^{-1} 2,4-\mathrm{D}+1.0 \mathrm{mg} . \mathrm{L}^{-1}$ Zeatin, rapid callus induction and also more callus proliferation from stem explants were detected. Results indicate on callus induction that, Zeatin was more successful than Kin or 2, 4-D, but other combinations directly developed a shoot. Callus obtained from stems explant was friable, white and yellow, while callus from leaf explants was green.
\end{abstract}

Keywords: Carnation plant, Explant Source, Dianthus caryophyllus, 2,4-D, Zeatin.

\section{Introduction}

Dianthus caryophyllus, is a common name carnation that is a member of the Caryophyllaceae family, developed about 2,000 years ago, raised in many areas of the world and assumed to be a Mediterranean native. Carnation is one of the foremost common commercial flowers, ranking beside Roses in grandeur. D. caryophyllus is a perennial herbaceous plant with a length of up to $80 \mathrm{~cm}$. The leaves are greyish to bluegreen, soft, up to $15 \mathrm{~cm}$ in length (Madhuri \& Barad, 2018). The stems are woody at the root, with herbaceous branches. D. caryophyllus is a medicinal value. These have largely become used in the treatment of stomach aches and teeth, in the treatment of wounds such as cardiovascular, cardiac, alexi- and vermifugal diseases. Traditionally, medicines are used to cure injury in China, Japan and Korea, gastrointestinal conditions, and various other diseases (Chandra et al., 2016). D. caryophyllus contains a variety of secondary metabolites such as alkaloids, triterpenes, coumarins, phenolic acids, anthocyanins, essential oil, pelargonidin, isosalipurposide, volatile oil and other chemical compounds; that benefit Pharmaceuticals in various diseases such as 
anti-cancer, anti-viral, anti-microbial, antifungal, insecticide, repulsive, antioxidant, rheumatoid, and analgesic effects (Al-Snafi, 2017). In addition, the majority of plants produce a small number of secondary metabolites. In addition, other factors, such as the excessive collection of unsustainable agricultural practices, urbanization, pollution and climate change, are contributing to plant extinction. Tissue culture techniques may therefore be an alternative method for maintaining a sustainable supply of plant material for the production of biologically active compounds on a continuous basis under industrial controlled conditions (Espinosa-Leal et al., 2018; Al-Birawee \& Nasser, 2019). Plant tissue culture techniques are used as an alternative treatment strategy of secondary metabolites where the plant content is insufficient or difficult to access and the synthesis of such metabolites is low in intact plants (Mahood et al., 2018; Chandran et al., 2020). Callus induction is a method for plant regeneration. Diverse factors, for example plant growth regulators, explants, cultivation conditions and culture vessels, have an impact on induction (Espinosa-Leal et al., 2018; Al-Asadi et al., 2019).

Maurya et al. (2020) identified the best induction of callus in Dianthus caryophyllus with a complex combination of BAP and 2, 4D using nodal and leaf explants. Callus gave effective results in the development of somatic embryogenesis and early genetic culture studies to improve Dianthus caryophyllus. Jorapur et al. (2018) obtained $100 \%$ of the induction of callus from petal explants cultivated on MS media containing a combination of $1.5 \mathrm{mg} . \mathrm{L}^{-1} \quad 2.4-\mathrm{D}$ and 0.5 mg. $L^{-1}$ NAA. These results highlight the importance of the characteristic of plant growth regulators and explants for the induction of callus. The goal of the current study is to analyze the impact of plant hormones and leaf and stem explants on $D$. caryophyllus callus induction.

\section{Materials \& Methods}

Seeds of D. caryophyllus washed over clean water for fifteen minutes and afterwards transported to the air flow room cabient, seeds disinfected with $2 \% \mathrm{NaOCl}$ for fifteen minutes and after wards washed with distilled water 2 - 3 times. Sterile seeds were grown with MS medium (Murshige \& Skoog, 1962) lacking plant hormones for germination, and then seeds incubated at $25 \pm 2{ }^{\circ} \mathrm{C}$ below $16 \mathrm{~h}$ of photoperiod at a light intensity of 3000 lux in the growth chamber. Agar was applied after changing the $\mathrm{pH}$ to 5.8 .

Explants (leaf and stem) obtained from seedlings that were grown on MS medium complemented by various concentrations of Kin, 2,4-D and Zeatin in order to choose the best concentrations, combinations of auxin and cytokinin and type of explants for callus induction. Reasonable concentrations of each plant growth were combined to assess the following:

\section{A-Callus induction from leaf explants}

Leaves explant harvested from seedling that cuts into small pieces $4-5 \mathrm{~cm}$ in length which were grown on MS medium complemented by different concentrations of $\operatorname{Kin}(0.0,0.5$, 1.5, 2.5 or $\left.3.5 \mathrm{mg} . \mathrm{L}^{-1}\right)$ and 2, 4-D (0.0, 1.5, $2.5, \quad 3.5$ or $\left.4.5 \mathrm{mg} . \mathrm{L}^{-1}\right)$ as well as combinations were assessed. Data were reported as callus fresh and dry weights and callus induction percentage after two months.

\section{B-Callus Induction from stem explants}

Stem explants obtained from seedlings 4-5 $\mathrm{cm}$ long and grown on medium MS, complemented by varying concentrations of Kin $\left(1.5,2.0,2.5\right.$ or $\left.3.0 \mathrm{mg} . \mathrm{L}^{-1}\right)$ and 2.4-D 
(0.2, $0.4,0.6$ or $\left.0.8 \mathrm{mg} . \mathrm{L}^{-1}\right)$. Fresh weight of callus was reported after two months.

\section{C-Callus induction from stem explants by using Zeatin}

For the combinations of (Kin $0.4 \mathrm{mg} \cdot \mathrm{L}^{-1}+$ 2,4-D $2.0 \mathrm{mg} . \mathrm{L}^{-1}$ ) as a control medium for callus induction from stem explants, Zeatin was added to the medium with additional amounts $\left(0.0,0.4,0.8\right.$, or $1.0 \mathrm{mg} . \mathrm{L}^{-1}$ for any form of callus medium ten replicates were used. The automated Statistical System-SAS (2012) was used to classify the effect of differentiating variables on the sample parameters.

\section{Results \& Discussion}

\section{Induction of callus from leaf explants}

Fresh and dry weight results from leaf explant that induction of callus are shown in table (1). Although leaf explants produced a small quantity of callus in some combinations, there was no induction of callus in control during the culture period. Also, the results described in this table show that in some combination of Kin and 2, 4-D, the percentage $(\%)$ of callus induction was $20 \%$ after two months, while the mean value was $90 \%$ at $4.5 \mathrm{mg} . \mathrm{L}^{-1}$ of 2 , 4-D. This 2, 4-D concentration exhibited the highest fresh weight reached $210.1 \mathrm{mg}$ and $3.5 \mathrm{mg} . \mathrm{L}^{-1}$ 2, 4-D, it registered $157.4 \mathrm{mg}$ of callus obtained by leaf explants, regarded to be the maximum induction percentage $(90 \%$ and $80 \%$ ). 2,4-D was more valuable than Kin or a combination of both in the induction of callus. The rise in auxin concentration raised the percentage of explants showing callus induction but decreased the callus fresh and dry weight. Among other combinations there have been no significant differences. All callus induction noted was green within combination (Fig 1-A).

\section{Callus induction from stem explants}

During the two months of cultivation, stem explant established callus at various concentrations from Kin and 2, 4-D, but response was increases after increased levels of Kin and 2, 4-D in the medium. A mixture of $0.2 \mathrm{mg} . \mathrm{L}^{-1} \mathrm{Kin}$ and $2.0 \mathrm{mg} . \mathrm{L}^{-1}$ 2, 4-D registered value $1453.6 \mathrm{mg}$ fresh weight of callus (Table 2), with a combination of 0.4 mg.L $\mathrm{L}^{-1} \mathrm{Kin}$ and $2.0 \mathrm{mg} . \mathrm{L}^{-1}$ 2.4-D, the stem explant chose to respond to the highest callus induction. This combination formed 2826.4 $\mathrm{mg}$, the highest fresh weight in this culture. Green compact callus was appeared by some combinations, but yellow- green friable callus observed at $0.2 \mathrm{mg} . \mathrm{L}^{-1}$ of Kin and $2.5 \mathrm{mg} . \mathrm{L}^{-1}$ of 2,4-D (Fig: B). Stem explants were found to be more responses to the induction of callus than leaf explants.

\section{Induction of callus from stem explants by using Zeatin}

Callus induction from stem explant showed a significant difference in the mass of callus, based on cytokinin type and concentration. The rapid growth of callus as well as increased production of callus was obtained on the MS medium complemented by Zeatin. The overall fresh weight of callus was 5314 $\mathrm{mg}$ at $1.0 \mathrm{mg} . \mathrm{L}^{-1}$ Zeatin relative to those grown on the control medium containing 2.0 mg.L. $\mathrm{L}^{-1}$ 2, 4-D and $0.4 \mathrm{mg} . \mathrm{L}^{-1}$. Zeatin formed direct shoots at $0.4 \mathrm{mg} . \mathrm{L}^{-1}$ and $0.8 \mathrm{mg} . \mathrm{L}^{-1}$. Similar results were obtained by Shiba \& Mll (2005) who reported that in Dianththus acicularis, treatment with Zeatin produced high frequencies of cell division and callus formation by protoplast explants that isolated from the leaf. 
Table (1): Effect of Kin and 2, 4-D combination on fresh and dry weights and percentage of $D$. caryophyllus leaf explants initiation callus after two months of cultivation on MS medium.

\begin{tabular}{|c|c|c|c|c|}
\hline 2,4-D (mg. $\left.\mathrm{L}^{-1}\right)$ & Kin mg. $\left.L^{-1}\right)$ & $\begin{array}{l}\text { Percentage response of } \\
\text { leaf explants }(\%)\end{array}$ & $\begin{array}{l}\text { Fresh } \\
\text { weight }(\mathrm{mg})\end{array}$ & $\begin{array}{l}\text { Dry } \\
(\mathrm{mg})\end{array}$ \\
\hline 0.0 & 0.0 & 0 & . & . \\
\hline 0.0 & 0.5 & 0 & . & . \\
\hline 0.0 & 1.5 & 0 & . & . \\
\hline 0.0 & 2.5 & 0 & . & . \\
\hline 0.0 & 3.5 & 0 &. &. \\
\hline 1.5 & 0.0 & 30 & 70.5 & 6.3 \\
\hline 1.5 & 0.5 & 20 & 40.7 & 4.2 \\
\hline 1.5 & 1.5 & 0 &. &. \\
\hline 1.5 & 2.5 & 0 & . & . \\
\hline 1.5 & 3.5 & 0 &. &. \\
\hline 2.5 & 0.0 & 50 & 90.2 & 11.7 \\
\hline 2.5 & 0.5 & 20 & 30.3 & 1.7 \\
\hline 2.5 & 1.5 & 0 &. &. \\
\hline 2.5 & 2.5 & 20 & 83.2 & 9.8 \\
\hline 2.5 & 3.5 & 0 & . & . \\
\hline 3.5 & 0.0 & 80 & 157.4 & 34.3 \\
\hline 3.5 & 0.5 & 20 & 143.5 & 10.8 \\
\hline 3.5 & 1.5 & 0 & . &. \\
\hline 3.5 & 2.5 & 30 & 160.2 & 28.9 \\
\hline 3.5 & 3.5 & 20 & 211.6 & 12.2 \\
\hline 4.5 & 0.0 & 90 & 210.1 & 36.3 \\
\hline 4.5 & 0.5 & 60 & 163.6 & 30.1 \\
\hline 4.5 & 1.5 & 40 & 150.3 & 25.7 \\
\hline 4.5 & 2.5 & 40 & 253.7 & 35.4 \\
\hline 4.5 & 3.5 & 20 & 142.2 & 18.9 \\
\hline \multicolumn{2}{|c|}{$\begin{array}{c}\text { LSD } \\
(\mathrm{P} \leq 0.05)\end{array}$} & $8.026 *$ & $17.441 *$ & $6.194 *$ \\
\hline
\end{tabular}

*Indicate statistical significance compared to the control.

Kanwar \& Kumar (2010) examined the impacts of multiple types of plant growth regulators on the initiation of callus in $D$. caryophyllus and found that buds were directly formed by a medium containing only Zeatin or a mixture of NAA and IAA. Kaur (2014) observed green, hard compact and fast- growing of callus in D. caryophyllus by stem explants that culture on MS medium contained Zeatin. Cytokinin is among the most widely often used studied plant growth regulators in the form of callus. The medium supplemented with Zeatin improved the capacity of callus induction and remained viable for calli after six weeks of culturing. Grunennvaldt et al. (2020) found that genotypes display the varied capacity to the formation of callus and shoots in Ilex paraguariensis when Zeatin was used. 
Mahood, / Basrah J. Agric. Sci., 34(2): 100-106, 2021

Table (2): Effect of Kin and 2, 4-D combinations on fresh weight of callus that induction stem explants of $D$. caryophyllus after two months of culture on MS medium.

\begin{tabular}{lll}
\hline $\begin{array}{l}2,4-\mathrm{D} \\
\left(\mathrm{mg} . \mathrm{L}^{-1}\right)\end{array}$ & Kin $\left(\mathrm{mg} . \mathrm{L}^{-1}\right)$ & Fresh weight of callus $(\mathrm{mg})$ \\
\hline 1.5 & 0.2 & 261.4 \\
\hline 1.5 & 0.4 & 745.7 \\
\hline 1.5 & 0.6 &. \\
\hline 1.5 & 0.8 &. \\
\hline 2.0 & 0.2 & 1453.6 \\
\hline 2.0 & 0.4 & 2826.4 \\
\hline 2.0 & 0.6 &. \\
\hline 2.0 & 0.8 &. \\
\hline 2.5 & 0.2 & 781.2 \\
\hline 2.5 & 0.4 & 1102.1 \\
\hline 2.5 & 0.6 &. \\
\hline 2.5 & 0.8 &. \\
\hline 3.0 & 0.2 &. \\
\hline 3.0 & 0.4 & 853.6 \\
\hline 3.0 & 0.6 &. \\
\hline 3.0 & 0.8 &. \\
\hline LSD & & $163.864^{*}$ \\
$(\mathrm{P} \leq 0.05)$ & & \\
\hline
\end{tabular}

Table (3): Effect of addition of Zeatin to MS medium contained combination of Kin and 2, 4$D$ on fresh weight callus that induction from stem explants after two months.

\begin{tabular}{|c|c|c|c|}
\hline $\operatorname{Kin}\left(\mathrm{mg} \cdot \mathrm{L}^{-1}\right)$ & $\begin{array}{l}2, \quad 4-\mathrm{D} \\
\left(\mathrm{mg} . \mathrm{L}^{-1}\right)\end{array}$ & $\begin{array}{l}\text { Zeatin } \\
\left(\mathrm{mg} . \mathrm{L}^{-1}\right)\end{array}$ & Fresh weight (mg) \\
\hline 0.4 & 2.0 & 0.0 & 1462 \\
\hline 0.4 & 2.0 & 0.4 & - \\
\hline 0.4 & 2.0 & 0.8 & - \\
\hline 0.4 & 2.0 & 1.0 & 5314 \\
\hline \multicolumn{3}{|l|}{$\operatorname{LSD}(\mathrm{P} \leq 0.05)$} & $237.85 *$ \\
\hline
\end{tabular}

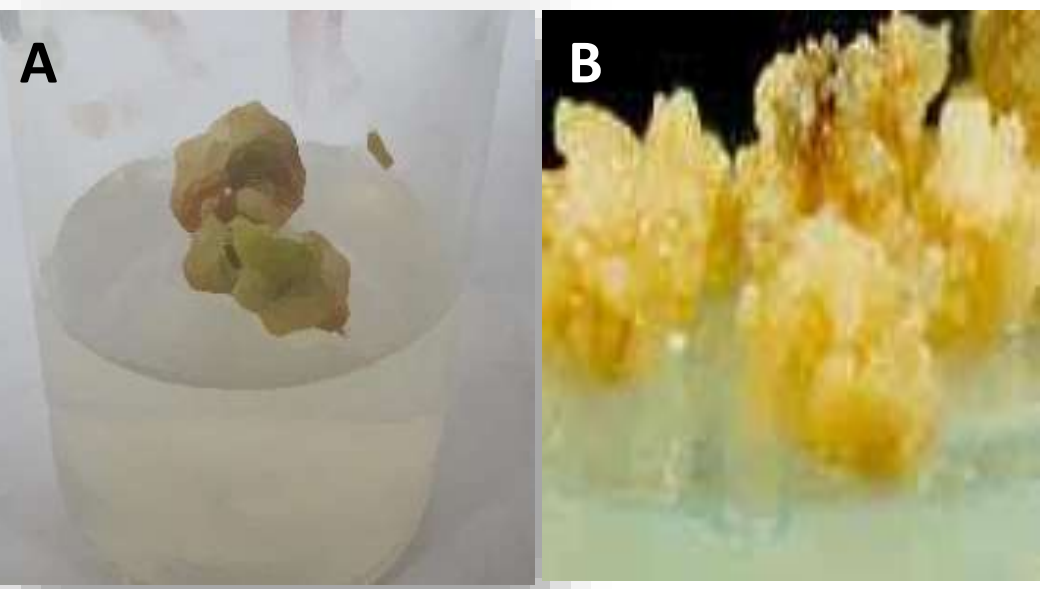


Mahood, / Basrah J. Agric. Sci., 34(2): 100-106, 2021

Fig. (1): Callus induction of $D$. caryophyllus (A) Callus induction from leaf explants. (B) Callus induction from stem explant.

\section{Conclusions}

As indicated in the current study, the mass of callus formed from stem explants is higher than the results from leaf explants. Treatment with Zeatin as well cause higher induction of callus in D. caryophyllus. For future research, our research may also be enhanced in various directions for more development of callus, high efficiency or less period, including: initiating callus from roots that are rich in bioactive compounds, utilizing various types of auxin, and then using the procedure for induction of callus from leaf explants.

\section{Acknowledgements}

This research was carried out in University of AlQadisiyah, so many thanks to all the staff member for their support from beginning until the end of this study.

\section{Conflict of interest}

The author doesn't have any probable conflict of interest regarding the publisher's policy requirements.

\section{Orcids}

H. E. Mahood.: https://orcid.org/0000-0002-7482-5625

\section{Reference}

Al-Asadi, A. Z., Abdulwahid, A. H., \& Al-Mayahi, A. M. W. (2019). The effect of thidiazuron on callus and in vitro shoots development of Date Palm (Phoenix dactylifera L.) cv. Barhee. Basrah Journal of Agricultural Sciences, 32, 258-265. https://bjas.bajas.edu.iq/index.php/bjas/article/view/90/82

Al-Birawee, A. R., \& Nasser, A. K. (2019). Gel extraction from caper fruits (Capparies spinosa L.) and assess its effectiveness as antioxidants. Basrah Journal
Agricultural Sciences, 32, 74-84. https://bjas.bajas.edu.iq/index.php/bjas/article/view/111/98

Al-Snafi, A. S. (2017). Chemical contents and medical importance of Dianthus caryophyllus- A review. IOSR Journal of Pharmacy, 7, 61-71. www.iosrjournals.org

Chandra, S., Rawat, D. S., Chandra, D., \& Rastogi, J. (2016). Nativity, phytochemistry, ethno botany and pharmacology of Dianththus caryophyllus. Research Journal of Medical Plant, 10, 1-9. http://docsdrive.com/pdfs/academicjournals/rjmp/20 16/1-9.

Chandran, H., Meena, M., Barupal, T., \& Sharma, K. (2020). Plant tissue culture as a perpetual source for production of industrially important bioactive compounds. Biotechnology Reports Journal, 20, 6:e00450.https://doi.org/10.1016/j.btre.2020.e00450.

Espinosa-Leal, C. A., Puente-Garza, C. A., \& GarcíaLara, S. (2018). In vitro plant tissue culture: means for production of biological active compounds. Planta, 248, 1-18. https://doi.org/10.1007/s00425018-2910-1

Grunennvaldt, R. L., Degenhardt-Goldbach, J., Brooks, P., Tomasi, F. A. H., Tran, T., Gomes, E. N., \& Deschamps, C. (2020). Callus culture as a new approach for the production of high added value compounds in Ilex paraguariensis: Genotype influence, medium optimization and compounds identification. Academia Brasileira de Ciências. 92 ,

http://www.alice.cnptia..br/alice/handle/doc/1126527

Jorapur, S., Jogdande, N., \& Dhumale, D. (2018). Petal callus mediated de novo regeneration of shoots in carnation (Dianthus caryophyllus L.). The Pharma Innovation Journal, 7, 218-222. https://www.thepharmajournal.com/archives/2018/v ol7issue1/PartD/7-1-38-894

Kanwar, J. K., \& Kumar, S. S. (2010). Effect of growth regulators, explants and their interaction on shoot regeneration in Carnation. Advances in Horticultural Science, 24, 115-121. https://doi.org/10.17221/3750HORTSCI

Kaur, K. (2014). In vitro mass cloning at Dinthus chinesis. A horticulture important plant. Dissertation 
Mahood, / Basrah J. Agric. Sci., 34(2): 100-106, 2021

reported, Department of Biotechnology, Thapar University. http://hdl.handle.net/10266/3120

Madhuri, G., \& Barad, A. V. (2018). Flowering parameters of carnation (Dianthus caryophyllus L.) varieties under protected condition influenced by NPK nutrients through foliar spray. The Pharma Innovation Journal, 7, 105-108. https://www.thepharmajournal.com/archives/2018/v ol7issue8/PartB/7-5-177-645.pdf

Mahood, H. E., Alwash, B. J., \& Ibrahim, K. M. (2018). Improvement of alkaloids yield using phenylalanine as a precursor supplemented to Morina oleifera L. callus cultures. Biochemical and Cellular Archives, 18 ,

913-919.

http://www.connectjournals.com/achivestoc2.php?fu lltext=2866300H_913-919.pdf\&\&bookmark=CJ033216\&\&issue_id=Supplement\&\&yaer=2018M

Maurya, R., Sharma, M., Yadav, M. K., Kumar, G., \& Kumar, M. (2020). In Vitro high-frequency callus induction in carnation (Dianthus caryophyllus L.) cultivar "IRENE" Plant Cell Biotechnology and Molecular Biology, 20, 1363-1368. file:///C:/Users/huda/AppData/Local/Temp/Paper178

Murashige, T., \& Skoog, F. (1962). A revised medium for rapid growth and bioassays with tobacco tissue culture. Plant Physiology, 15, 473-497. https://onlinelibrary.wiley.com/doi/epdf/10.1111/j.1 399-3054.1962.tb08052.x

SAS. (2012). Statistical Analysis System, User's Guide. Statistical. Version 9.1 $1^{\text {th }}$ ed. SAS. Inst. Inc. Cary. N. C.

USA. https://support.sas.com/documentation/onlinedoc/sta t/indexchapter.html

Shiba, T., \& Mll, M. (2005). Plant regeneration from mesophyll- and cell suspension-derived protoplasts of Dianthus acicularis and characterization of regenerated plants. In vitro Cellular and Developmental Biology -Plant, 41, 794-800. https://doi.org/10.1079/ivp2005712

\section{Dianthus caryophyllus تأثير منظمات نمو النبات والجزء النباتي في استحثاث الكالس لنبات هدى عناية ماهود1 1 قسم البستنة وهندسة الحدائق، كلية الزر اعة-جامعة القادسية، العراق}

المستخلص: لدراسة إعادة التكوين السريع لنبات القرنفل Dianthus caryophyllus خارج الجسم الحي, عدة تراكيز من منظمات النمو (2,4-D) 2,4-Dichlorophenoxy Acetic Acid و وبعدة تداخلات من كليهما تم اختبارها لاستحثاث الكالس من الاوراق والسيقان باستعمال الوسط الغذائي موراشيج وسكوج (MS). سجلت النسبة المئوية لاستحثاث الكالس والوزن الطري ولون وبنية الكالس بعد شهرين من الزراعة. كان الوسط المثالي لانتاج الكالس من اجزاء الاوراق هو وسط MS مجهز بـ 4.5 ملغم/تتر 2,4-D ـ اظهر التداخل بين 0.4 ملغم/لتر من Kin +2.0 ملغم/لتر 2,4-D الافضل في تحفيزً الكالس من الساق. كما تم اختبار تاثير اضافة منظم النمو Zeatin بتراكيز مختلفة (0.0 ، 0.4 ، 0.8 أو 1.0 ملغم / لتر) الى الوسط الغذائي المجز بتراكيز من Kin و 2,4-D اكثرانتاجية و نمو اسرع للكالس الناتج من الساق. لقد كان وسط MS الذي يحتوي على 0.4 ملغم/لتر Kin + 2.0 ملغم/لتر 2,D-D + 1.0 ملغم/لتز Zeatin اسرع في استحثاث وتكاثر الكالس من الساق. تشير النتائج في استحثاث الكالس إلى أن

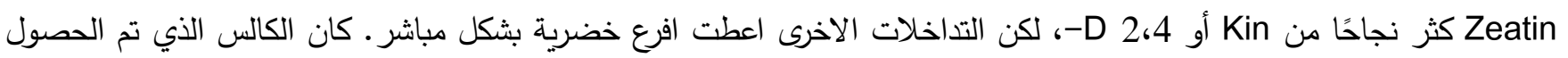
عليه من السيقان هشًا، أبيض، أصفر بينما كان الكالس الناتج من الاوراق أخضر اللون. الكلمات المفتاحية: نبات القرنفل، مصدر النبات، Dianthus caryophyllus، Zeatin 2,4-D. 